\title{
A Survey of Federal Agency Response to President Clinton's Executive Order No. 12898 on Environmental Justice
}

\author{
Denis Binder, Colin Crawford, Eileen Gauna, M. Casey Jarman, Alice Kaswan, Bradford C. Mank, Catherine \\ A. O'Neill, Clifford Rechtschaffen, and Robert R.M. Verchick
}

Denis Binder is a Professor of Law at Chapman University. Colin Crawford is an Associate Professor of Law at the Thomas Jefferson School of Law. Eileen Gauna is a Professor of Law at Southwestern University. M. Casey Jarman is an Associate Professor of Law and Director of the Environmental Law Program at the William S. Richardson School of Law, University of Hawaii. Alice Kaswan is an Associate Professor of Law at the University of San Francisco. Bradford Mank is the James B. Helmer Jr. Professor of Law at the University of Cincinnati. Catherine A. O'Neill is an Associate Professor of Law at the James E. Rogers College of Law at the University of Arizona. Clifford Rechtschaffen is a Professor of Law at Golden Gate University. Robert R.M. Verchick is the Marvin Rich Scholar and a Professor of Law at the University of Missouri-Kansas City.

Each of the authors reviewed the response of a specific federal agency to Executive Order No. 12898, relying extensively, but not solely, upon the responses to a prepared survey. Professor Binder then summarized and edited the individual responses into this cohesive, comprehensive study with the substantial assistance of the other authors. We gratefully acknowledge the assistance provided by the representatives of the individual agencies in preparing and responding, often at great length, to our inquiries. We further thank Prof. Marc Poirier of Seton Hall Law School for his assistance. The authors, other than Professor Binder, would like to extend their special gratitude to Professor Binder for his skill, hard work, patience, and diplomacy in working with a diverse group of academics on this collaborative project.

\section{[31 ELR 11133]}

In an effort to address the well-documented and serious problem of environmental justice in the United States, President William J. Clinton issued Executive Order (EO) No. $12898^{1}$ on February 11, 1994. The EO represented the culmination of a century of rapid changes in society's attitudes toward the placement of hazardous facilities in poor, disadvantaged, and minority communities, as well as the denial of services to these communities. This survey examines the impact of the EO on federal agencies. $\stackrel{2}{ }$

Environmental justice is not a problem unique to the late 20th century. Majoritarian societies have historically discriminated against minority groups. $\stackrel{3}{-}$ For example, the post-World War II exodus to the suburbs in the United States partially reflected an effort by affluent members of society to insulate themselves from the more unpleasant realities of modern-day living. Through zoning and other land use planning tools, economically deprived persons and sundry undesirable facilities were excluded from the affluent suburbs. Zoning was often an effective tool of exclusion.

As a result, locally undesirable land uses (LULUs) became concentrated in economically poor, politically impotent neighborhoods, often those with a minority population. Common examples were the placing of industrial and waste facilities in minority communities, and the subsequent imposition of "urban renewal" programs on those communities. The glaring disparity resulted in considerable legal debate and litigation, which, through the 1980s, focused on exclusionary zoning ${ }^{4}$ and the denial of services. $\underline{5}$

A seemingly isolated incident in 1967 changed the terms of the discourse: a demonstration by 500 primarily AfricanAmerican students at Texas Southern University protesting the drowning of an eight-year-old girl at a landfill in an African-American neighborhood in Houston, Texas. This incident and others ultimately led Prof. Robert D. Bullard, 
then a sociology professor at the University of California at Riverside, to follow up and publish an epochal study in 1983, on the neighborhoods surrounding landfills and waste sites in Houston. ${ }^{6}$ He found that minority and [31 ELR 11134] low-income communities surrounded these facilities. The U.S. General Accounting Office (GAO) also published in the same year a study, which showed a correlation between the siting of hazardous waste landfills and the demographics of the surrounding communities. ${ }^{7}$ A study in 1987, by the United Church of Christ Commission for Racial Justice, supported the conclusions of the earlier Bullard and GAO studies. $\frac{8}{}$ These three reports clearly documented the patterns of low-income and minority populations living near industrial and hazardous waste facilities.

With the publication of these studies, public attention rapidly focused on the area of "environmental racism," which soon metamorphosized into "environmental justice." The broad concept of environmental justice became one of our country's major civil rights issues by the end of the 20th century.

The term "environmental justice" is subject to several interpretations. On the one hand, it can be applied in a narrow sense to the siting of LULU's in minority and low-income communities-the classic environmental justice scenario. These communities are usually African American, Hispanic, or Native American.

On the other hand, the term can apply in a broader sense to such issues as the failure of environmental enforcement and cleanup programs to respond to the needs of less affluent communities, or to the public health concerns of minority communities. It may also be illustrated by more stringent enforcement of environmental and public health statutes in affluent communities. The problem of lead-based paint poisoning in inner-city communities is an example of the broader definition. $\cdot$

The U.S. Environmental Protection Agency's (EPA's) website describes environmental justice as

the fair treatment and meaningful involvement of all people regardless of race, color, national origin, or income with respect to the development, implementation, and enforcement of environmental laws, regulations, and policies. Fair treatment means that no group of people, including a racial, ethnic, or socioeconomic group, should bear a disproportionate share of the negative environmental consequences resulting from industrial, municipal, and commercial operations or the execution of federal, state, local, and tribal programs and policies. $\frac{10}{}$

President Clinton responded to the environmental justice developments by issuing the EO on February 11, 1994. $\stackrel{11}{ }$ The three general purposes of the EO are:

1. To focus attention of federal agencies on the human health and environmental conditions in minority and low-income communities with the goal of achieving environmental justice;

2. To foster nondiscrimination in federal programs that substantially affect human health and the environment; and

3. To give minority and low-income communities greater opportunities for public participation in, and access to, information on matters relating to human health and the environment.

Each federal agency is to "make achieving environmental justice part of its mission." Every federal agency must consider the effects of its policies and decisions on the health and environment of low-income or minority neighborhoods. In addition, agencies should issue detailed reports outlining how they plan to eliminate disparate environmental efforts.

The EO has been in effect for seven years - a sufficient time to warrant an assessment of its implementation and effects. $\stackrel{12}{~ T h e ~ l o n g-t e r m ~ e f f e c t s ~ o f ~ t h e ~ E O ~ c a n ~ o n l y ~ b e ~ m e a s u r e d ~ d e c a d e s ~ f r o m ~ n o w, ~ b u t ~ a ~ p r e l i m i n a r y ~ a s s e s s m e n t ~ c a n ~}$ provide a sense of whether progress is being made. To that end, the Environmental Justice Law Professors Consortium, comprised of law professors from around the country, prepared a survey for selected federal agencies to assess the governmental response to the EO. $\underline{\underline{13}}$ The agencies surveyed are the U.S. Departments of Agriculture (USDA), $\underline{14}$ Energy (DOE), ${ }^{\underline{15}}$ the Interior (DOI), $\underline{\underline{16}}$ Justice (DOJ), ${ }^{17}$ and Transportation (DOT), $\underline{18}$ EPA,$\underline{19}$ the U.S. Department of Housing and Urban Development (HUD), $\underline{20}$ and the National Institute of Environmental Health Sciences (NIEHS)..$\underline{1}$ 
To standardize the survey, we developed a questionnaire that was sent to the agencies. The questionnaire contained 23 questions covering 8 areas: staff and training; environmental strategies, status reports and monitoring; interpretation of the EO; public participation; National Environmental Policy Act (NEPA) 22 compliance; programs; enforcement; and interagency coordination.

The purpose of the survey is not only to measure the response of selected federal agencies, but also to assess the impact of the EO; to wit, has it had a substantive impact, or is [31 ELR 11135] it merely of symbolic significance? We are attempting to assess the progress the federal government has made toward integrating environmental justice into its policies, programs, and activities, as well as whether federal agencies have made a substantial effort to direct and deliver environmental services to environmental justice communities. We are also interested in seeing if an agency's goals are matched by reality. This independent report will also allow federal agencies to compare their efforts with those of other agencies. One of our goals is that this survey will be the first in a periodic series to assess the ongoing efforts of federal agencies to advance environmental justice.

Our report is the product of the individual agency surveys, published documents, and the transcript of the Sixteenth Meeting of the National Environmental Justice Advisory Council. $\stackrel{23}{3}$ This Article reports the results of our survey.

A preliminary caveat is necessary. The agency responses are self-reporting and self-described. We accepted their responses and reports at face value and did not seek to independently verify whether they were accurate, inaccurate, or over- or under-inclusive. Silence on a particular query should not, therefore, be construed to imply the presence absence, or nonexistence of an agency program or action. $\stackrel{24}{ }$ This report is therefore primarily, but not exclusively, descriptive in nature.

Several other preliminary observations are in order. First, no agency claims to have dropped any specific environmentally harmful project because of environmental justice (hereinafter EJ) concerns. However, the situation may be, as expressed by the DOT, that EJ concerns are considered in the front end of the planning process. In this respect, increased sensitivity, at the beginning of the planning stage, will result in EJ benefits, which might not otherwise have occurred. In addition, other agencies, such as the NIEHS, do not engage in siting decisions.

Second, as is common with large organizations, the effectiveness of a program or goal often depends upon the tone set at the top of the agency. Clear leadership and direction at the Secretarial level is important both in implementing the goals of the EO and in being able to assess the effectiveness of the agency's response. The DOI and the DOJ are weak in this respect because of the decentralized nature of their operations.

Third, most agency efforts are directed at the broader definition of EJ — the delivery of environmentally related services to poor and minority communities. Many of these activities seem to partake more of the nature of traditional anti-poverty efforts and the providing of services aimed at everyday environmental problems and children's health issues, such as lead paint poisoning, rather than the large siting problems. These efforts are a significant step in furthering the goals of the EO. The EO was a catalyst in getting agencies to assess what they were doing-a necessary, preliminary step. Such actions are, however, only the first in a series of actions envisioned by the EO.

Fourth, federal agencies have clearly made substantial progress to increase, improve, or refine public participation in information gathering and dissemination, if not in decisionmaking. Almost every agency reports substantial community outreach and involvement in the form of workshops, information sessions, publications, and grants. EPA, HUD, the NIEHS, and the USDA publish materials in languages other than English. EPA, DOE,, 25 and the DOI ${ }^{26}$ have web pages that address EJ. DOE and the USDA have provided computers and technical training to low-income and minority communities. $\underline{27}$

Fifth, the number of federal employees working full time on EJ issues appears very limited—indeed, almost nonexistent. Many agencies, however, report that a number of employees spend a greater or lesser amount of their work on EJ issues. The USDA, for example, reported that a full-time position existed for an EJ coordinator, but that the position was currently unfilled. Similar positions were reported to exist within the USDA's departments.

Finally, and significantly, the number of agencies reporting assessments of their EJ activities was small. Even when an annual report was initially prepared, follow up reports were lacking. ${ }^{28}$ This lack of assessment makes it difficult to fully 
evaluate how agencies are implementing the EO, and to compare agencies. A set of meaningful evaluative criteria needs to be implemented in order for agencies to assess their efforts.

This Article is divided into three major sections. The first section provides a cross-agency summary of responses to the areas covered in the questionnaire. It is followed by a more detailed description of each agency's reported efforts to comply with the EO, and by our conclusion.

\section{Cross-Agency Summary}

\section{Interagency Coordination}

Section 1-102 of the EO created the Federal Interagency Working Group on Environmental Justice (IWG), which is chaired by the Administrator of EPA. The IWG, in 1999, established an Integrated Federal Interagency Environmental Justice Action Agenda (Action Agenda), pursuant to which a number of demonstration projects have been undertaken to promote EJ. EPA's Office of Environmental Justice (OEJ) published, in November 2000, a report on the success of the Action Agenda. The report describes 15 demonstration projects in which 2 or more federal agencies are working together with state, local and tribal governments, private partners, and community representatives to address EJ challenges [31 ELR 11136] in meaningful ways. ${ }^{29}$ EPA is the lead or co-lead agency on six of the projects. DOE has also taken the lead on a few of the projects.

The DOJ has supported several demonstration projects carried out by the IWG. It also reports that it has been very active in developing and promoting the Action Agenda. The DOJ, HUD, EPA, and state and local governments around the country have embarked upon a nationwide initiative to enforce the Residential Lead-Based Paint Hazard Reduction Act. The joint enforcement effort has been targeted toward landlords with prior lead violations, including a history of lead-poisoned children on their properties.

All the federal agencies identified in the EO (the USDA, the U.S. Departments of Commerce and Defense, DOE, the U.S. Department of Health and Human Services (HHS), HUD, the DOI, the DOJ, the DOT, EPA, and the U.S. Department of Labor) are meeting regularly to exchange information on how they can work together and implement EJ initiatives within their respective programs. HUD and the NIEHS specifically report interagency cooperation. NIEHS conferences and workshops target not only the public, but also public and private agencies, such as EPA, the Agency for Toxic Substances and Disease Registry, the Centers for Disease Control, HUD, the Health Resources and Services Administration (HRSA), nongovernmental organizations (NGOs), other National Institute of Health (NIH) institutes, and foundations. The DOI has a designated person in each of its bureaus to coordinate with other federal agencies on EJ matters through the IWG. EPA has often worked with other agencies, including the USDA and HUD, in promoting brownfield redevelopment. $\underline{30}$

\section{Title VI $\underline{31}$}

Often overlooked in the issuance of the EO is an accompanying Presidential Memorandum, which requires federal agencies "providing funding to programs affecting human health or the environment to ensure that their grant recipients comply with Title VI of the Civil Rights Act of 1964."를 Title VI prohibits agencies receiving federal funding from taking actions that discriminate against minorities. $\frac{33}{-}$ Most federal agencies have promulgated regulations prohibiting recipient agencies from taking actions that would have a disproportionate impact on minorities.

Title VI has been at the center of EPA's EJ programs. The Agency had done little to enforce its existing Title VI regulations prior to 1993. However, in the wake of the 1994 Presidential Memorandum, EPA established the Office of Civil Rights (OCR) to address Title VI and other discrimination issues, including internal employment discrimination claims. EPA published on June 27, 2000, the Draft Revised Guidance for Investigating Title VI Administrative Complaints Challenging Permits (Draft Revised Investigation Guidance ${ }^{34}$ to clarify how EPA would determine whether a permit decision by a recipient would cause adverse disparate impacts that violate Title VI. The Agency simultaneously issued its Draft Guidance for EPA Assistance Recipients Administering Environmental Permitting Programs (Draft Recipient Guidance), which discusses a range of possible approaches to minimize the likelihood that a complaint will be filed against a recipient. Recipients of Agency funding are encouraged to undertake activities that are consistent with the EO, such as establishing effective public participation programs, translating documents into languages other than English where appropriate, collecting data about possible adverse impacts, and reducing or 
eliminating these impacts. The guidance also contains a detailed discussion of how the Agency will investigate and analyze Title VI claims.

The USDA also monitors Title VI compliance by agency fund recipients. The USDA proposed a new regulation concerning civil rights compliance by recipients of federal [31 ELR 11137] funds under USDA programs. $\underline{6}$ The USDA's agencies are to analyze and evaluate the participation of minorities, women, persons with disabilities, and low-income populations in the design, development, and implementation of agency programs and activities where participation of the affected public is required or desired.

In the DOJ, the Attorney General is charged by a different EO, EO No. $12250, \frac{37}{}$ with the coordination, implementation, and enforcement of Title VI. This role has been delegated to the Civil Rights Division. The division has a Coordination and Review Section that coordinates federal agency responses when multiple Title VI complaints are filed with different agencies. The section has committed a significant percentage of its resources to the Title VI complaints that raise EJ issues.

Few, if any, Title VI complaints raising EJ issues against DOJ recipients have been filed. ${ }^{38}$ The USDA and the DOI are also unable to provide information on the number of Title VI complaints, alleging discrimination by fund recipients, the departments have received since 1996.

HUD reports that a number of its formal training programs have focused on compliance with Title VI. HUD recently provided 160 HUD compliance investigators with training on EJ and Title VI. As of April 2001, HUD had 25 open EJ complaints. The complaints concern a wide variety of activities, such as: public housing built on contaminated land; the exercise of eminent domain to condemn minority homes and businesses for public works projects; disparate financing of services, such as water, sewer, and other community development functions; development of housing projects having a disparate impact on minority communities; as well as economic development projects that fail to meet the needs of and have an unnecessarily detrimental impact upon minority populations. Many of the complaints are based on one or more legal theories, including Title VI, Title VIII (which prohibits discrimination relating to housing), and § 109 of Title I of the Housing and Community Development Act of 1974 (which prohibits racial discrimination by recipients of HUD community development block grants). The respondents against whom the complaints are alleged are usually an individual, city, or state who received HUD funds. $\frac{39}{}$

\section{Programmatic Impacts}

The programmatic impacts of EO No. 12898 have varied by agency. For example, EPA views Title VI as the center of the Agency's EJ programs. Significantly, EPA created the OCR to address Title VI and other discrimination issues. On the other hand, no consistent EJ program or programs are characteristic of the DOI. The DOT issued a department-wide order incorporating Title VI as part of its official policy and practices. EJ concerns are incorporated into the decisionmaking processes of the Federal Highway Administration (FHwA) and the Federal Transportation Administration (FTA). The DOT's emphasis is to put EJ considerations into the front end of the planning process.

Similar to the DOT, HUD integrates EJ considerations into existing programs, and has highlighted four program areas:

1. Empowerment zones and enterprise communities;

2. Fighting childhood lead paint poisoning;

3. Brownfield redevelopment; and

4. Colonias, which involve the housing and development needs in impoverished areas along the U.S.-Mexico border.

HUD stated, in a 1996 report on implementing the EO, that it "will promote sound environmental considerations in community development and housing policies that, at the same time, will preserve housing affordability and encourage rural and urban economic growth and private sector investment." $\underline{40}$ 


\section{NEPA}

The Council on Environmental Quality (CEQ) has the leading role in defining how federal agencies shall implement the EO in their NEPA assessments. The CEQ issued, in 1997, its Environmental Justice Guidance Under the National Environmental Policy Act. ${ }^{41}$ The CEQ's position is that environmental assessments (EAs) under NEPA should address any significant EJ impacts on minority and low-in-come communities, discuss feasible measures for mitigating such impacts, and involve the affected community in the process. A critical caveat with respect to NEPA is that it is simply procedural. Therefore, while agencies must disclose and discuss significant impacts, including EJ impacts, and discuss possible mitigation measures, they are not obligated to change their decisions on the basis of these adverse impacts or to implement possible mitigation measures. $\underline{42}$

EPA has several NEPA responsibilities. First, it must conduct EAs under the Act for the Agency's internal projects. ${ }^{43}$ In order to address the EO in the context of its NEPA obligations, the Agency issued a draft guidance statement in April 1996, incorporating EJ concerns into the Agency's own NEPA compliance analysis. ${ }^{44}$ Second, pursuant to $\S 309$ of [31 ELR 11138] the Clean Air Act (CAA), EPA reviews all environmental impact statements (EIS) prepared by other federal agencies. $\frac{45}{}$ The EO directs EPA to use its $\S 309$ review authority to ensure other federal agencies analyze environmental impacts on minority groups and low-income populations. EPA cannot force another agency to rewrite a NEPA statement, but it can issue a negative review if the NEPA statement fails to address a significant issue, such as environmental impacts on low-income and minority communities. EPA may also refer the issue to the CEQ for further review.

The EPA's Office of Federal Activities issued, in April 1998, its Final Guidance for Incorporating Environmental

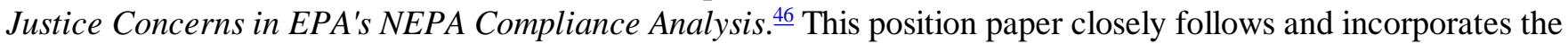
CEQ's 1997 framework for analyzing EJ issues in the preparation of NEPA assessments. ${ }^{47}$ EPA, in April 1999, issued its Final Guidance for Consideration of Environmental Justice in Clean Air Act $\S 309$ Reviews. $\frac{48}{}$ This document again is closely based on the earlier CEQ position as well as the April 1998, Office of Federal Activities' final guidance. $\underline{.9}$

The CEQ's guidelines for incorporating EJ concerns in NEPA documents were sent to all DOI bureaus, who were advised to use them. In addition, EPA's EJ guidance for NEPA was also sent to the bureaus on an information-only basis. The DOI has advised its bureaus to use the disparate treatment definition available in the CEQ's guidance, but has not developed its own definition.

The DOT issued a department-wide order on EJ. A significant part of the order is $\S 8$, which requires a set of determinations to be made as part of the normal NEPA process. $\frac{.3}{}$

Some agencies, such as the NIEHS, rarely prepare EIS in course of their activities. The DOJ follows the CEQ's NEPA guidelines for agency actions, such as by the Bureau of Prisons and the Immigration and Naturalization Service, that trigger NEPA assessment. They report that the NEPA statements explicitly address the EJ implications of proposed actions. EJ considerations are also part of DOE's NEPA review process.

\section{Community Outreach/Public Participation}

The federal agencies, as a whole, have engaged in extensive community outreach programs. EPA, for example, has programs in place to assist communities in monitoring and reducing pollution. Publications are available in languages other than English. Significantly, EPA has encouraged state environmental agencies to improve their public participation efforts, especially for low-income and minority communities. For example, the Draft Recipient Guidance has several recommendations to foster a "meaningful" public participation process: using open and transparent procedures; providing understandable information necessary for effective community participation, including distributing documents in languages other than English (for significant populations whose primary language is not English); and by offering clear explanations for permit decisions. $\underline{54}$

HUD already had extensive public participation and community outreach procedures in place when the EO was promulgated, so no changes were necessary in this respect. Notices are bilingual when necessary. For example, the materials prepared for HUD's lead paint poisoning educational programs are translated into foreign languages to reach diverse communities. HUD also refers communities to EPA or the CEQ for explanations of relevant environmental 
requirements.

HUD has prepared materials to explain its environmental programs and obligations to communities. The Agency has prepared an easy-to-read, nontechnical document, Choosing an Environmentally "Safe" Site, for use by HUD program participants, grant recipients, and others. Since many HUD programs are designed for minority and low-income communities, the guidance could be viewed as consistent with the EO. HUD has also developed tools that will allow communities to better assess environmental conditions in their neighborhoods. HUD's Healthy Communities Environmental Mapping is a free internet service that provides the location of HUD-funded activities, and then allows users to select EPA information on brownfields, hazardous waste, air pollution, and wastewater discharges near HUD projects. In addition, HUD's Community 2020 Software is a geographic information system that can identify minority and low-income populations and the environmental risks they experience. This software thus has the potential to help identify minority and low-income populations experiencing disproportionately high and adverse human health effects. Finally, HUD's website has a section on EJ that provided links to the Agency's EJ strategy and implementation report, the Community 2020 Software, and to a number of EPA EJ information sites. $\underline{55}$

As with HUD, the DOI has long had public participation as part of its charge because of its land and resource management responsibilities. For example, Bureau of Land Management [31 ELR 11139] (BLM) planning documents require public participation before resource management plans are finalized. Similarly, the Mineral Management Service (MMS) is required to work with Native Alaskans.

The EO, though, has had the effect of "heightening" the awareness of the DOI employees of the obligation to reach out to the public. For example, in connection with possible development on the outer continental shelf, the MMS conducted "scoping" meetings in Native American communities, and used Inuit translators at public hearings on a draft EIS to present information. Similarly, the Bureau of Indian Affairs (BIA), with responsibility for historical indigenous sites on federal land, promised to have oral history related to the Chugach National Forest translated and transcribed.

The NIEHS reports that community outreach and public participation constitute key components of EJ grants. Workshops, professional society conferences and, at least four times a year, town meetings are held. The NIEHS also prepares materials in languages other than English. DOE and the DOT likewise have established extensive public participation programs.

On the other hand, community involvement/outreach efforts by the DOJ are left entirely to the individual attorneys handling a case. While some enforcement cases involved negotiated supplemental environmental programs (SEPs) with resultant benefits to impacted communities, the DOJ's efforts to encourage greater public participation seem relatively modest.

\section{Grants}

A strong overlap exists with community outreach programs and agency grants. DOE, EPA, HUD, and the NIEHS report the issuance of scores of grants to community-based organizations and academic institutions. EPA's OEJ reported over 800 EJ grants. The NIEHS has 19 active grants through the United States to such varied groups as African-Americans, migrant farm workers, Laotians, Alaskan natives, economically disadvantaged Caucasians, Latinos, Asian/Pacific Islanders, and Southeast Asian women. Several federal agencies prepared a directory of grant sources for Native Americans. The document is available on an EPA website. $\underline{56}$

\section{Program Evaluations}

Introspective assessment of the effectiveness of programmatic EJ activities was, in most cases, found to be lacking..${ }^{57}$ In other words, while agencies could describe what they were doing, many did not evaluate the effectiveness of the activities. This lack of critical assessment may exist because of the relative newness of many of the programs and initiatives; sufficient time may not as yet have elapsed before meaningful assessment can occur. In addition, some agencies may not generally engage in systematic program evaluation.

Nevertheless, the NIEHS regularly evaluates the work both of its grantees and its total EJ program. EPA also evaluates its grant programs. For example, OEJ issued a report, Environmental Justice Small Grants Program: Emerging Tools

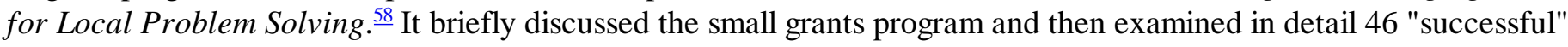


EJ small grants programs from all 10 Agency regions. The report provided a brief description of most projects, followed by an assessment of the successes and strengths.

On the other hand, the GAO has criticized EPA for failing to require recipients to report adequate information about the success of brownfield projects. ${ }^{59}$ The lack of information makes it difficult to assess performance. EPA has conducted case studies to determine if significant EJ problems exist with its brownfield projects.

\section{Personnel}

Most agencies have distributed EJ responsibilities to numerous individuals and do not have personnel assigned full time to EJ matters. For example, in the DOJ's Environmental and Natural Resources Division, one attorney spends approximately $50 \%$ of his time on interagency EJ initiatives, and another spends 5-10\% of her time coordinating departmental activities. Two civil rights attorneys devote approximately $20 \%$ of their time on EJ matters, while a staff person in the Executive Office of Weed and Seed spends 25\% of the time on such matters.

Every region of EPA has its own OEJ or a primary focal point for EJ activities. $\underline{60}$

At HUD, one staff member in the Office of Community Viability, which is part of the Community Planning and Development Office, spends approximately $20 \%$ of his time on EJ policy, guidance training, and public affairs. Since many HUD projects necessarily entail the preparation and filing of NEPA statements, approximately 20 staff responsible for the environmental reviews devote about 5\% of their time on the EJ implications of the projects under review. An additional five to six staffers in the Office of Fair Housing and Equal Opportunity spend about 20\% of their time on EJ in the context of complaints brought under Titles VI or VIII.

The NIEHS has four professional level staff and additional support staff involved in EJ activities. DOE has an Environmental Justice Coordinator in the Office of Economic Impact and Diversity, as well as contact personnel in its major programs and field centers.

The USDA has 18 agencies and 6 offices with staff whose time is devoted at least in part to addressing EJ issues at the national level.

\section{Affected Populations}

Obviously the attention of the agencies is focused on minority and low-income communities. Variations on a theme can exist though. For example, the USDA's definitions of "minority," [31 ELR 11140] "minority population," and "low-income population" closely parallel the EO. However, the Agency adds a twist by reflecting its agricultural orientation. It highlights particular concern for "migrant farm workers and other geographically dispersed/transient persons." $\underline{61}$

HUD defines the term "minority" to apply to any group that is not Caucasian and not otherwise nonminority white. With respect to the implementation of the EO, HUD defines "low income" in accordance with the CEQ's definition provided in its guidance. The definition of "low income" used for purposes of the EO may differ therefore from the definition that governs eligibility for various HUD housing programs.

Bureaus within the DOI have substantial independence, but they are directed to use the census definition of poverty for "low income." They were also directed to use the CEQ's definitions in the EJ guidance, unless they had reason to do otherwise.

Specific attention is also focused on indigenous populations. President Clinton, on May 14, 1998, issued EO No. 13084, Consultation and Coordination With Indian Tribal Governments, which requires federal agencies to engage in meaningful consultation with tribal authorities when issuing regulations that will significantly affect them. $\frac{62}{} \mathrm{In}$ November 2000, the Indigenous Peoples Subcommittee of the National Environmental Justice Advisory Council (NEJAC) issued a Guide on Consultation and Collaboration With Indian Tribal Governments and the Public Participation of Indigenous Groups and Tribal Members in Environmental Decision Making. It was designed to implement EO No. 13084's goals. The OEJ assisted NEJAC in preparing the guide. On November 6, 2000, President Clinton issued EO No. 13175, $\frac{63}{-}$ which supercedes and strengthens the policy on tribal consultation expressed in the 
previous EO No. 13084.

The DOJ had earlier, in 1995, created the Office of Tribal Justice in an effort to establish an additional forum for tribes to communicate their concerns. The DOJ also issued, in November 1995, a sovereignty policy reaffirming the sovereign status of federally recognized tribes as domestic dependent nations..$^{64}$

HUD has developed extensive contacts with Native American tribes in its housing programs. HUD has built upon these relationships to often act as a liaison between the tribes and other agencies, such as EPA, who wish to contact the tribes about EJ programs and opportunities.

The USDA has also engaged in several steps specifically directed at Native Americans. The U.S. Forest Service co-hosted, with the Central Council of Tlingit and Haida Indian Tribes, an EJ workshop in March 2001, in Ketchikan, Alaska. The Forest Service is also preparing a National Resource Book on American Indian and Alaska Native Relations. The book is designed to provide guidance to the Agency's work with American Indian tribes regarding the tribes' special governmental status, cultures, rights, and interests stemming from treaties, statutes, and other sources. The resource book is expected to facilitate expanded cooperative relationships between the Forest Service and tribes with respect to forestry and resource management programs.

The USDA's National Resource Conservation Service (NRCS) $\underline{65}$ attempted to improve services to Native American tribes, through such activities as organizing multi-agency funding to support a tribal outreach and proposing educational proposals to increase Native American participation in USDA programs. The USDA has also consolidated county sub-offices at tribal headquarters in counties having reservations within their borders.

In light of the EO direction that the DOI is to consult with tribes and the IWG to coordinate steps to be undertaken pursuant to the EO with respect to federally recognized tribes, the DOI chaired the working group on tribal consultation. The BIA was designated to oversee the preparation of a memorandum of understanding (MOU) with EPA, the Indian Health Service, and HUD. The MOU addresses roles and responsibilities for environmental issues on Indian lands. The four agencies are to meet regularly to address major environmental and health-related concerns as they develop. Apparently, this MOU has not been finalized.

\section{Individual Federal Agencies}

\section{EPA}

Carol Browner, Administrator of EPA during President Clinton's Administration, made EJ an important policy goal for the Agency. EPA is also in many respects the primary federal agency implementing the EO throughout the federal government.

EPA's OEJ plays a primary role in implementing the EO by providing grants to community groups, assisting other EPA departments with equity issues, and coordinating a large number of interagency activities. For example, the OEJ has provided over 800 EJ grants of between \$10,000 and \$ 20,000 to local community-based groups since 1994. In fiscal year (FY) 2001, \$ 1.5 million in such grants have been allocated, including \$ 500,000 for communities located near Superfund sites. $\frac{66}{}$ On the other hand, EPA has suspended funding for two additional programs: The CommunityUniversity Partnership Grants Program (11 grants totaling \$ 2.5 million to universities that form partnerships with disadvantaged communities) and The State and Tribal Environmental Justice Grants Program (10 grants for \$ 1 million).

EPA has awarded several larger grants as part of its brownfield programs to promote voluntary private clean-ups of moderately contaminated properties. During the Clinton Administration, then-Vice President Al Gore championed brownfield redevelopment. The Agency has awarded over \$ 157 million for various brownfield projects [31 ELR 11141] since 1993, not including additional millions for revolving loan funds or job training. ${ }^{67}$

EPA has initiated many actions to increase public participation by low-income and minority groups, including translating documents into languages other than English. The Agency released, in August 2000, Public Involvement in Environmental Permits: A Reference Guide, ${ }^{68}$ after consulting with NEJAC and the Environmental Council of States. The report discusses existing public participation requirements for several EPA permitting programs and lists a number 
of Agency headquarters and regional contacts and resources. It also includes additional tools for promoting public participation that are related to the EO's goals. EPA discusses the possibility of awarding grants to communities to independently hire technical experts to ensure unbiased information. Other suggested techniques raised include community interviews, informal meetings with stakeholders, and the creation of citizen advisory groups to solicit information on citizen concerns and views about proposed facilities. The report further examines how federal or state regulators can create a public involvement plan for proposed facilities to enable the agency to work effectively with both the community and the applicant. This discussion builds on NEJAC's model plan for public participation as well as earlier agency policies on public participation.

On December 28, 2000, EPA published a Draft Public Involvement Policy (Draft Policy), $\underline{69}$ which is intended to update the Agency's 1981 Public Participation Policy. For example, the new Draft Policy discusses the use of the Internet and web pages to disseminate information. ${ }^{70}$ The Draft Policy is designed to encourage public participation. It is not binding, however; instead, it "relies heavily on the sound use of discretion by Agency officials." 71 The six-step public participation process described in the Draft Policy is similar to that established in 1981, but the new approach places greater emphasis on early outreach and consultation actions by Agency officials with a broad range of stakeholders. In particular, the Draft Policy emphasizes the involvement of those lacking the resources to participate

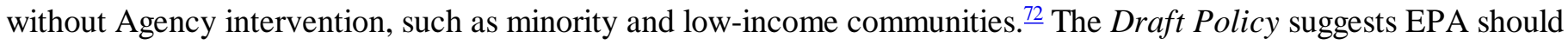
make special efforts to reach these groups. However, in light of the nonbinding status of these recommendations, it does not require the Agency to spend additional money or resources in these outreach efforts.

Many of EPA's activities entail noncontroversial activities, such as awarding community grants and translating documents. The Agency has been less likely to take stands that industry or state officials might oppose. EPA has, for example, spent much more on brownfield redevelopment than on EJ projects, or on reform of the permitting process and the establishment of more protective standards.

EJ became a significant component of EPA's permit review process when the independent U.S. Environmental Appeals Board (EAB) ${ }^{73}$ held that EPA has a duty to apply EJ whenever it has the discretionary authority to do so. $\underline{74}$ The EAB has reviewed 10 cases involving the EO.$\underline{75}$ Six of them involved CAA prevention of significant deterioration (PSD) permits, two were Resource Conservation and Recovery Act (RCRA) permit cases, and the remaining two involved underground injection control permits under the Safe Drinking Water Act (SDWA). The challenges were generally brought by local citizens living near the permitted activity, or who otherwise opposed the permit. National environmental organizations sometimes joined the proceedings. Although the board allowed affected citizens to raise EJ issues in the appeals, the EAB denied relief to them in every case. The EAB's record of rejecting EJ challenges is consistent with its generally restrictive approach to appeals. The EAB usually grants review only if it finds a "clearly erroneous finding of fact or conclusion of law, or [if the permit] involves an important matter of policy or exercise of discretion that warrants review." $\underline{6}$ As a practical matter, the local communities often lack the economic resources to effectively challenge the Agency's decision, thereby preventing them from articulating "their concerns in a manner likely to prompt" the EAB to second-guess the regional EPA decisionmakers responsible for the challenged agency action. $\underline{77}$

Section 1-103 of the EO requires agencies to adopt EJ strategies that address enforcement of health and environmental statutes in areas with minority and low-income populations. $\stackrel{78}{ }$ EPA's 1995 Environmental Justice [31 ELR 11142] Strategy ${ }^{79}$ represented that the Agency would use its enforcement discretion to focus on EJ issues raised by violations in communities disproportionately harmed by environmental pollution. The deputy assistant administrator for enforcement and compliance during the Clinton Administration pledged that the Agency and its regional offices would strengthen their enforcement efforts in areas with high levels of pollution. ${ }^{80}$ Indeed, in December 2000, Region II released an interim EJ policy that included enforcement guidelines targeting high pollution areas.

However, NEJAC's enforcement subcommittee pointed out that no empirical evidence shows EPA is actually increasing its enforcement efforts in these areas. Furthermore, the EPA's Draft Recipient Guidance merely addresses permitting issues and explicitly reserves the issue of discriminatory enforcement by state or local recipients for future guidance.

The OEJ, in April 1996, issued an EJ implementation plan, which discussed EPA's success in implementing the five

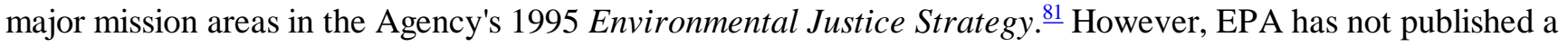


comprehensive review of its compliance with the EO since the 1996 report. For example, the 1998 Environmental Justice Biennial Report: Moving Towards Collaboration/Constructive Problem Solving did not systematically assess the extent of the Agency's compliance with the EO. It simply described many of the Agency's programs and activities.

Significantly, EPA has undertaken many activities in recent years to promote environmental justice, but without explicitly referring to the EO. The explanation may be that EPA recognizes the existence of ample legal authority in existing federal environmental statutes.

EPA has special programs to assist communities in monitoring and reducing pollution. From 1995 thorough 1999 the Environmental Justice through Pollution Prevention (EJP2) program provided over \$ 15 million for 198 grants. $\underline{\text { 2 }}$ The program was temporarily suspended for FY 2000 pending an evaluation of the program. In August 2000, Eastern Research Group, Inc., prepared a report for EPA concerning 107 EJP2 grants issued from 1995 to 1997. It contained final reports from the grantees about their success. $\frac{83}{}$ The report was largely based on these responses, rather than on input from community, industry, or governmental officials who may have played a role in the project. The report, basing its findings on surveys, interviews, and anecdotal evidence, found the EJP2 program was generally successful, especially when the grant recipient was able to involve the stakeholders and existing organizations in the project. EPA planned to award \$ 750,000 in EJP2 grants for FY 2001. $\frac{84}{}$

EPA also engages in studies. For example, a great unknown in recent years is the extent to which a community's health problems may be related to its location near a Superfund site. The Agency has initiated a site-specific epidemiological study of residents living near the Lower Darby Creek Superfund site as an attempt to engage in a much more comprehensive assessment than the Agency normally conducts at Superfund sites.

\section{USDA}

The USDA promulgated a departmental regulation (DR) on December 15, 1997, DR 5600-2, which outlines the Agency's strategy. It also described, in a 1996 report submitted to President Clinton, actions it has undertaken to promote EJ.

DR 5600-2 includes a departmental policy to incorporate EJ concerns into the USDA's programs and activities in order to identify, mitigate, and prevent adverse human health or environmental effects. It also commits the USDA to providing opportunities for minority and low-income populations to participate in planning and decisionmaking on matters that affect their health or environment. Efforts to promote EJ are not limited to NEPA compliance. However, EJ concerns are typically raised and tracked through the NEPA process.

The USDA noted it has partially implemented its EO strategy by expanding the criteria for its impact analysis to include racial and ethnic demographics, income levels, health sensitivity, environmental exposures, past regulatory actions and interactions with communities, integration of land use management systems, and subsistence consumption patterns. The Agency has also reported integrating EJ criteria into its technical and financial assistance programs, facility management programs, hazardous materials transportation use and disposal practices, $\underline{85}$ Agency reinvention initiatives, and its Five-Year Strategic Plan and Long-Term Strategic Plan under the Forest and Rangeland Renewable Resources Act.

The EO strategy includes a commitment to revise regulations, as applicable, to incorporate EJ principles and objectives, and to revise management plans, delegations of authority, mission statements, organizational structures, functional statements, position descriptions, and performance standards for affected employees and agencies. Progress on implementation is addressed in civil rights reports prepared by each of the USDA's agencies. Specific mechanisms to assess effectiveness are being developed.

The USDA's Under Secretary for Natural Resources and Environment has overall leadership responsibility for implementation of the EO. An EJ Steering Committee has been formed to advise the Under Secretary both with regard to compliance with the EO and concerning effectiveness in addressing EJ issues. The Steering Committee is to meet [31 ELR 11143] twice yearly. Agency heads are also required to report annually to both the Under Secretary and the Steering Committee, detailing their practices and accomplishments toward ensuring compliance with the EO.

The USDA identified a number of specific initiatives or programs that contribute to its efforts to comply with the EO. $\frac{86}{}$ 
A representative sample includes Water 2000, a partnership between Rural Utilities Services, federal, state, and local agencies, foundations, and private lenders, which seeks to provide targeted loans, grants, and technical assistance to improve small community and Colonias water systems. The goal is to bring the systems into compliance with the SDWA.

Under the Urban Tree House Program, the USDA committed itself to working with community residents in the Naval District and southeast Washington, D.C.; East Atlanta, Georgia; Chicago, Illinois; Midcity, Louisiana; and New York City to develop EJ programs that respond to local concerns.

The USDA works through the 1890 Capacity Building Grants Program to strengthen agricultural research and related activities at the 1890 Land Grant institutions. The USDA is initiating a parallel program at universities that traditionally support Hispanic communities, and plans to commence a third program to support tribal colleges. The Limited Resource Farmers' Initiative encourages socially disadvantaged individuals to enter or continue in farming by allocating funds to the 1890 institutions to provide training to small farmers to improve their management techniques and inform them about how to avail themselves of USDA services.

In addition, several USDA agencies have undertaken specific initiatives or programs within their respective mission areas. For example, in the Urban Resource Partnership, the Forest Service and the NRCS, in cooperation with six other federal agencies and state and local governments, provided funding and technical assistance to eight cities $\stackrel{87}{ }$ with significant minority populations.

Another program was Commencement 2000, which sought to work with young people of color, women, and immigrants in disadvantaged urban school systems to enhance urban natural resources and beautify open spaces.

The Forest Service, under the Environmental Roundtable, in collaboration with other organizations such as the National Association for the Advancement of Colored People (NAACP), the College Fund, the National Council of Negro Women, and EPA, provides assistance through education, outreach, research, and business development. The Forest Service also works with educational outreach programs, such as the American Indian Higher Education Consortium and the Southwest Polytechnic Institute for Forest Service career development, classroom education, and seasonal work programs.

The NRCS committed resources to provide additional conservation services to urban and suburban areas with significant minority populations. These efforts included soils information, soils surveys, erosion/sedimentation control, flood plain management, and assistance with community gardening and native plants. The NRCS has provided funding for specific EJ projects, such as the Minority Environmental Association's Earth Day Event and water quality testing program, the Coalition to Restore Urban Waterways' (CRUW) program to develop guidelines for restoration of urban waterways by training urban community groups, and a cooperative agreement with Tuskegee University to develop guidelines for implementing an EJ policy.

The NRCS funded a research initiative to gather information on potential EJ issues. The Southern Food Systems Education Consortium, comprised of 61890 land grant colleges, conducted 743 face-to-face interviews in 11 "Black Belt" states and provided the survey results to the Agency. The published results ${ }^{88}$ concluded minority populations were well aware of environmental problems involving air, water, soil, and human health. They rated their overall community environmental quality significantly lower than the non-minority respondents. .99 They also viewed EJ as a more significant issue than did non-minority respondents. The low-income respondents rated the quality of relevant government services lower than the high-income respondents. Indeed, the low-income respondents tended to be unaware of NRCS services that could address environmental problems.

The Cooperative State Research, Education, and Extension Service (CSREES) has developed programs in Spanish and other languages to train migrant and resident farm workers in safe handling procedures for pesticides and other chemicals. The CSREES also collects, maintains, and analyzes information on the consumption patterns of populations that rely on fish and wildlife for subsidence. The CSREES publishes guidelines reflecting the latest scientific information for evaluating human risks associated with the consumption of pollutant-bearing fish or wildlife. Fact

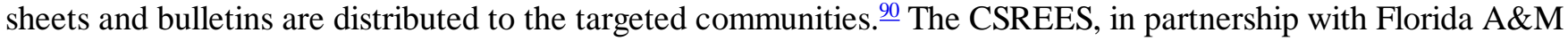
University, is compiling a database on minority and women scientists with the aim of facilitating cultural diversity in scientific activities such as peer review panels, program review teams, and advisory committees. 
The USDA translates documents pertaining to pesticide impacts on health for non-English speaking populations. For example, the Texas Lower Rio Grande Boll Weevil Eradication program had documents translated into Spanish, as well as having translators available at public meetings for farm workers and their families. Food safety publications and videos are also available in Spanish.

\section{[31 ELR 11144]}

\section{$D O E^{11}$}

Public participation and EJ were not historically part of DOE's culture. DOE's response to the EO has been to make EJ

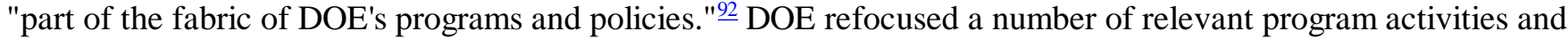
implemented procedural changes to meet the challenge of the EO.

DOE outlined methods in its Environmental Justice Strategy ${ }^{93}$ to reduce disproportionately high and adverse human health or environmental impacts of its operations and facilities in low-income and minority communities. DOE followed up with a progress report a year later..$^{94}$ This report listed a large number of environmental cleanup and other projects undertaken or complete, which the DOJ claimed would benefit the affected communities. However, many of these efforts are traditional environmental cleanup programs mandated by statutes that predate the EO. In addition, some of the projects may have been initiated prior to the issuance of the EO. $\underline{95}$

A number of DOE offices are offering EJ training to educate and sensitize managers and staff. The Office of Environmental Safety and Health conducts health studies in communities around DOE sites. The Office of Energy Efficiency and Renewable Energy is using EJ considerations in its review process for awarding funding.

DOE is the lead agency on a few of the interagency demonstration projects, including an American Indian and Alaska Native Environmental Justice Roundtable held in Albuquerque, New Mexico..$\underline{6}$ Federal agencies, in cooperation with tribes, tribal organizations, and other interested parties, discussed and identified means to address the tribal cultural, religious, economic, social, legal, and other issues related to EJ in Indian Country.

DOE is also assisting communities in meeting the "digital divide" through technology sharing. It has provided excess computers and technical assistance to establish community technology centers. For example, the High Park/Aragon community near the Savannah River site used computers and training provided by DOE in partnership with EPA to research enforcement issues. The community then applied for and received an EPA brownfields grant.

DOE sponsors several community outreach and participation programs. For example, it sponsors the Environmental Justice Resource Center at Clark-Atlanta University. $\frac{97}{}$ This project serves as a research, policy, and information clearinghouse on issues related to EJ, civil rights, land use planning, and other equity issues. DOE has also entered into a cooperative arrangement with the National Conference of Black Mayors. It is assisting in the rebuilding of Princeville, North Carolina, which was devastated by Hurricane Floyd. $\underline{98}$

The Office of Environmental Management, in partnership with EPA's Office of Federal Facilities Restoration, Savannah State University, and Citizens for Environmental Justice, supports workshops and public involvement programs for adversely impacted communities near the Savannah River site. Activities include workshops, literature and exhibits on radiation, weekly radio programs, and interaction with site managers and the Savannah River's Citizen Advisory Board.

DOE's Samuel B.P. Massey Chairs of Excellence program consists of nationally and internationally recognized environmental experts from nine historically black colleges and universities and one Hispanic-serving institution. They assist the National Conference of Black Mayors and disadvantaged communities in improving sewage systems, solid waste incineration, and other municipal environmental issues..$\underline{99}$

The Office of Energy Efficiency and Renewable Energy provides a home modernization program for over 80,000 low-income residents. $\frac{100}{}$ The Office's Center for Sustainable Development operates a website in English and Spanish that provides information on green building, transportation, rural issues, resource efficiency, and economic issues. It has also provided communities with technology and training to participate in an increasingly digital world. 


\section{$H U D^{101}$}

HUD highlighted four program areas in which EJ considerations are incorporated. The first is its Empowerment Zone and Enterprise Communities (EZ/EC) program, which encourages development in low-income and minority areas suffering from pervasive poverty, high unemployment, and other social ills. HUD designated 6 EZs and 66 rural ECs in 1994, followed by an additional 20 urban EZs and 20 rural ECs in 1999. Designated communities receive various forms of federal funding, much of which is designed to encourage additional private investment. Environmental considerations are integrated into the planning process.

EJ concerns are highlighted in a number of demonstration projects. For example, HUD is involved in a brownfield redevelopment of an abandoned industrial site in Baltimore, Maryland. The new "Fairfield Ecological Industrial Park" will include environmentally friendly businesses. In Chicago, [31 ELR 11145] HUD will participate in the cleanup of 25 contaminated acres. Residents within the EC will be hired to conduct the cleanup.

The second area incorporating EJ concerns is HUD's lead-based paint initiative, to which HUD devotes substantial resources. HUD's efforts serve the dual goals of complying with the $\mathrm{EO}$ and fulfilling the requirements of the

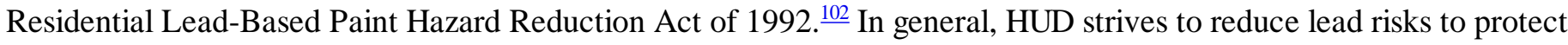
children's health, but in a manner that will not jeopardize the availability of low-income housing or cause property owners to abandon high-risk residential properties.

HUD has tested virtually all public housing built before $1978 \underline{103}$ for lead paint. Lead hazards are abated in replacement and renovated public housing units. HUD has also established a grants program, the Lead Hazard Control Grant program, to finance lead education, testing, and lead abatement in private low-income and minority housing.

Community education is an important part of HUD's lead programs. HUD and EPA jointly fund a toll-free telephone line (800-424 Lead) to provide information about lead hazards. All residents of HUD-associated housing ${ }^{104}$ receive a brochure describing the risks of lead poisoning and how to prevent it. HUD further works with the real estate industry to encourage the distribution of the pamphlet upon the sale or rental of pre-1978 housing. The 1997 Campaign for a Lead Safe America, launched by President Clinton, includes numerous public educational components, such as public service advertising, videos, and distribution of a book on lead safety. HUD also has available a CD-ROM, the "Residential Lead Desktop Reference," which provides community outreach materials, HUD guidelines, and a list of resources for those dealing with lead hazards.

HUD also requires all of its grantees under the Lead Hazard Control Grant program to conduct lead education programs. The state and local government grantees target the educational programs to the particular needs and cultural practices of local low-income and minority communities at risk. A wide variety of mechanisms are used to ensure that information about lead hazards reaches diverse audiences.

Furthermore, HUD leads a Task Force on Lead-Based Paint Hazard Reduction and Financing that is designed to explore how market forces can be used to reduce lead exposure while still maintaining the viability of affordable housing. HUD also works with other agencies in various efforts to document and study lead risks, and to develop standards for lead testing and abatement.

The third area incorporating EJ concerns is that of brownfield cleanups and redevelopment projects. Many poor and minority populations reside in close proximity to abandoned industrial facilities. Efforts to clean up and redevelop these properties are considered critical to improving environmental conditions and revitalizing depressed communities. HUD has therefore worked closely with EPA in various initiatives associated with the cleanup and redevelopment of brownfields. For example, the agencies provide technical assistance to communities on financial, technical, and environmental issues.

Twenty federal agencies, including HUD, joined together in 1997 to implement the Brownfields National Partnership Action Agenda. EPA and HUD partnered in furthering the program, which included a range of activities, such as funding community development, adopting cleanup and redevelopment strategies, and researching the impacts of brownfields on inner cities. The partnership provides models for cleanup and redevelopment and is designed to facilitate environmental cleanups and economic development. The partnership has designated 16 showcase 
communities to serve as models. These communities receive technical and financial support as well as the assistance of a federal employee to coordinate the cleanup and redevelopment. HUD has also entered into an MOU with the U.S. Army Corps of Engineers to provide technical assistance and resources for economic development.

Since 1998, states receiving block grants pursuant to HUD's Community Development Block Grant program can allocate the funds for cleanup and economic redevelopment of brownfields. In addition, HUD has provided loan guarantees to communities engaging in brownfields development to improve their access to financing. HUD has provided Brownfields Economic Development Initiative (BEDI) grants in recent years to assist in the financing of brownfields secured by $\S 108$ loan guarantees.

The fourth program HUD highlights in connection with EJ is its Colonias program, which aims to provide housing and development needs to the impoverished areas along the U.S.-Mexico border. Many of these communities suffer from a lack of adequate sewer systems, water services, and housing. HUD has participated in EPA's Colonias Working Group to administer and monitor Colonias funds.

Pursuant to federal statutes, HUD has required the border states of Arizona, California, New Mexico, and Texas to set aside a certain percentage of their Community Development Block Grants to address housing and urban development problems in the Colonias. This money is frequently used to improve water and sewer services, and to provide housing assistance.

HUD's Rural Housing and Economic Development Grant program provides grants to improve housing conditions and create jobs in poor rural and Native American communities throughout the nation. Some of these funds are earmarked for Colonias. These grants are intended to create affordable housing and facilitate home ownership.

HUD's Colonias efforts are further facilitated by the funding of a Community Outreach Center at Texas A\&M University. The center mobilizes a range of university resources to further economic and community development in 10 Texas Colonias.

\section{DOI}

The responsibility for EJ oversight and initiatives at the DOI primarily rests with the Director of DOI's Office of Environmental Policy and Compliance. These duties include the implementation of EO No. 12898. The Director has other responsibilities, and cannot estimate what percent of his time is spent on EJ issues. No one at the DOI is charged solely with EJ compliance, and many of its efforts are diffused throughout the DOI. The DOI's compliance responsibilities mimic its organizational structure. A person in each of the DOI's eight bureaus is responsible for coordinating EJ issues, [31 ELR 11146] in addition to a staffer in the Solicitor's Office. $\frac{105}{}$ Nine individuals, therefore, have EJ responsibilities. They are scattered throughout the Washington, D.C., headquarters and regional offices.

The DOI issued a 27-page Strategic Plan on Environmental Justice in 1995. Although the Strategic Plan has not been updated, reports on EJ matters were presented to President Clinton between 1995 and 2000. The 1995 plan detailed four goals for implementing the EO, namely (1) involving minority and low-income communities in environmental decisionmaking; (2) providing EJ guidance to the DOI employees; (3) the use and expansion of scientific, research, and data collection on "innovative solutions to environmental justice-related issues"; and (4) the use of partnerships with grassroots, business, labor, community, and other groups. The plan then examined what has been done, and what can be done, with respect to each of these goals for each of the eight bureaus.

These reports detail the training efforts by DOI bureaus to promote EJ. For example, the U.S. Fish and Wildlife Service conducted NEPA training sessions around the country in FY 1996 to incorporate EJ issues into the analysis.

Due in part to the DOI's decentralized structure, no centralized process is in existence for identifying and tracking EJ-related matters within its jurisdiction. The eight bureaus are individually responsible for oversight of EJ matters within their respective jurisdictions. No consistent EJ policies, programs, or themes are characteristic of the DOI as a department. Significant variation exists in the way each bureau approaches EJ. The bureaus share information among themselves about their different initiatives.

Initiatives at the bureau level include efforts by the Office of Surface Mining to provide notice of all mining projects on 
tribal lands to native tribes, and the National Park Service's (NPS) effort in the Southwest, in conjunction with the Hispanic Radio Network, to provide information to Hispanics about the connection of the national parks to their cultural heritage. The NPS hopes to extend this service to Native peoples.

The MMS is gathering information on the effects of its offshore oil and gas program on EJ concerns in Alaska, including subsistence hunting. Traditional knowledge is sought, as well as the input of stakeholders, such as Alaska villages, Native whaling groups, and the North Slope Borough along the Beaufort Sea. ${ }^{106}$ The resulting study originated from Native American concerns expressed during a meeting in Barrow, Alaska, with the MMS in March 2000. Native American input and approval was fundamental to the study design. It includes a survey/questionnaire of the Inuit people of the North Slope regarding the observations and concerns.

Many times the EO was a reason, but not the sole reason, a program was initiated. EJ was simply a piece of the larger whole. For example, the U.S. Geological Survey's annual effort to train faculty at historically black colleges and universities in Geologic Information Systems and other developments in cartography may have been given a push by the existence of the EO, but it was the kind of thing that DOI bureaus were already on schedule to do.

\section{DOJ}

The DOJ's Environmental Justice Strategy, adopted in 1995, $\underline{107}$ sets forth a broad array of lofty objectives for the DOJ, including development of an enforcement strategy "to help ensure that all communities and persons live in a safe and healthful environment"; promoting the use of Title VI, including working with EPA to expedite investigations of civil rights claims; mediating disputes related to EJ through the DOJ's Community Relations Service; advising client agencies of their obligations under the EO; counseling state and local governments to work cooperatively with the federal government to further the goals of the EO; working with communities so that enforcement actions respond directly to environmental risks; and providing department-wide training and education. The DOJ simultaneously published Guidance Concerning Environmental Justice, which provides guidelines to determine if a matter raises EJ issues. The major criteria are the existence of disproportionate health or environmental effects, risks or exposures to an EJ community; past under-enforcement of environmental laws; and the denial of equal opportunity for meaningful community involvement in environmental decisions. $\underline{108}$

Efforts in implementing EO No. 12898 have been modest, but the DOJ does sensitize its employees to EJ issues in their case investigation and handling. The DOJ's efforts tend therefore to be ad hoc, depending in considerable degree on the judgment and initiative of individual attorneys. The 1995 Environmental Justice Strategy stated that the DOJ would develop a list of EJ enforcement priorities and a strategy for addressing these priorities. However, it apparently has not done so.

New hires receive training in EJ, and each litigating section was provided EJ training after the EO was signed. In addition, EJ concepts have been incorporated into various internal manuals and training materials, such as the U.S. Attorney's Training Manual on Civil Rights.

The primary contact on EJ issues is the Environment and Natural Resources Division. Two departmental workgroups help promote the goals of the EO- a Working Group on Environmental Justice that monitors the efforts of units within the DOJ, and a Working Group on Environmental Health Risks to Children, which was formed to enhance the DOJ's efforts to reduce environmental risks in communities.

Much of the legal implementation is left to the individual federal attorneys assigned to specific cases. DOJ attorneys are instructed to review each case to determine if it raises EJ issues. They may request more information from a referral agency or obtain relevant demographic data. ${ }^{109}$ Attorneys have used SEPs in case settlements to mitigate environmental harms in EJ communities. For example, the DOJ settled two enforcement actions against facilities in Chester, Pennsylvania. These settlements resulted in the funding of both a lead abatement project and a comprehensive asthma detection [31 ELR 11147] and treatment program in the local schools. $\frac{110}{}$ With the exception of a lead-based paint enforcement initiative, however, $\underline{111}$ the DOJ has not undertaken any targeted EJ investigations or formalized efforts to focus on compliance in EJ communities.

DOJ attorneys are instructed to review each case to determine if it potentially raises EJ issues, but identification largely rests with the judgment of individual attorneys. When EJ concerns are raised, DOJ attorneys are "encouraged" to 
consult with the affected community about enforcement matters, including possible remedies. The form of the community outreach is apparently left to the individual attorneys. The effectiveness of these outreach efforts is difficult to assess. $\frac{112}{2}$

The DOJ filed an amicus brief in support of private enforcement of EPA's Title VI regulations. This position was upheld by the Third Circuit, but vacated by the Supreme Court. $\underline{113}$

The DOJ instituted Operation Weed and Seed, which is a community-based strategy that focuses on weeding out crime, drug abuse, and gang activity, while seeding human services and neighborhood revitalization, with the goal of improving the quality of life in these communities. The program has been implemented in approximately 250 local communities, most of which are low-income communities and primarily inhabited by people of color. The DOJ surveyed these sites to identify concerns. Based on the survey results, the DOJ selected four sites for follow-up assistance: Phoenix, Arizona; Dade County, Florida; St. Louis, Missouri; and Portland, Oregon. $\underline{114}$

Local Operation Weed and Seed programs are guided by steering committees, which typically include the U.S. Attorney, mayors, chiefs of police, district attorneys, community residents, and others. Several Operation Weed and Seed sites have made environmental protection part of their community revitalization strategy, including brownfields restoration, targeted enforcement against illegal hazardous waste operations, establishment of citizen hotlines, and a lead hazard remediation program.

\section{DOT}

The DOT has identified EJ as a "flagship initiative" to ensure it remains a departmental priority. The DOT has created the Environmental Justice Review Committee, which includes senior DOT officials, to further EJ concerns and review the impact of transportation projects on minority communities. The committee has encouraged other units of the DOT to be aware of EJ issues, including the Federal Maritime Administration $\underline{115}$ and the Federal Aviation Administration (FAA), which oversees airport expansion plans.

The DOT has sponsored several workshops and retreats to educate DOT staff and others about EJ concerns and to explore avenues for future EJ initiatives. $\frac{116}{}$ As of January 2000, the FHwA's OCR had developed an antidiscrimination course, which included an EJ module. The course has been presented in at least 35 states. A videotape, "Reaching Out to Everyone," has also been produced and distributed. It addresses the need to involve traditionally unrepresented communities in transportation decisionmaking.

The DOT has also revised its highway regulations to incorporate EJ concerns into city planning. Metropolitan planning organizations (MPO) are now required to incorporate EJ issues in their annual certifications. The addition of EJ concerns to the written MPO certification is a significant step. MPOs must, for example, certify to the FHwA and the FTA that "the planning process is addressing the major issues facing the areas," that the planning process complies with Title VI and other statutes, and that the metropolitan transportation planning process includes a "proactive public involvement process" that seeks out and considers the needs of those traditionally underserved by existing transportation systems.

While EJ concerns did not appear to play a significant role in the DOT's decisionmaking in the past, the recent priority given EJ has affected at least two important decisions. Two local MPOs have received conditional certifications, and will not be certified unless they satisfy the DOT as to how they propose to incorporate EJ concerns into the analysis of transportation projects in their region. $\underline{\underline{117}}$

The DOT issued a department-wide order on EJ, DOT Order 5610.2, making Title VI part of its official policy and practices. $\stackrel{118}{~}$ This order, coupled with strong leadership at high levels of the DOT, provides the cornerstone for the DOT's EJ strategy. $\stackrel{119}{=}$ The order describes how the DOT and its operating administrations will integrate the goals of the [31 ELR 11148] EO in their daily operations. Integration plans are to emphasize explicit consideration of EJ effects, review of mitigation options, public involvement, and public access to information. The process standardizes and reinforces already established NEPA, Title VI, and other laws promoting social fairness in federal development. The order embraces the principles of EJ as policy and pledges to incorporate these principles in "DOT programs, policies, and activities." 
The order places particular importance on prevention strategies so that risks of discrimination can be identified early in the planning process and avoided at minimal cost. The policy, therefore, is one of prevention rather than reaction. In addition, the order provides that the DOT will establish an EJ data bank and "collect, maintain and analyze information on the race, color, national origin, and income level of persons adversely affected by DOT ... activities."

The most significant and controversial part of the order, as measured by public comments, is $\S 8$, Actions to Address Disproportionately High and Adverse Effects, which requires a set of determinations to be made as part of the normal NEPA process. $\frac{121}{}$ Pursuant to $\S 8$, the head of each DOT administration or component must be wary of "adverse effects" on EJ populations, must "determine whether programs, policies, and activities, for which they are responsible, will have an adverse impact on minority and low-income populations, and, if so, whether that adverse impact will be disproportionately high." $\underline{122}$ Effects are to be evaluated within the "totality of significant individual or cumulative human health or environmental effects," allowing decisionmakers to consider interrelated and cumulative impacts. $\underline{123}$

If DOT activity would create such adverse effects, then the conduct may not be pursued unless "further mitigation measures or alternatives, that would avoid or reduce the disproportionately high or adverse effects, are not practical." $\underline{124}$ Agency officials must also show that "less harmful alternatives" would impose other adverse social, economic, environmental, or human health impacts that are more severe or would involve increased costs of "extraordinary magnitude." $\underline{125}$

The FHwA issued its own EJ order on December 2, 1998, closely paralleling its parent's DOT order. $\frac{126}{2}$ The FHwA's order requires its own officials and staff to identify risks of discrimination early so that corrective actions can be taken. $\frac{127}{}$ The DOT shall inquire into the racial and socio-economic status of affected populations where practical and appropriate, and will consider steps to guard against discriminatory unfairness. $\frac{128}{}$ The FHwA will collect and maintain needed EJ data. $\underline{129}$

\section{NIEHS}

NIEHS, which is an agency of HHS, had initiated EJ programs prior to the issuance of EO No. 12898. Programs and conferences have been organized for the past decade. The NIEHS does not conduct specific EJ projects. Instead, it awards grants to community-based organizations and academic institutions. The purposes of the NIEHS-funded EJ research and educational programs are to bring together communities, scientists, and health care providers to improve public health outcomes in at-risk neighborhoods. The NIEHS has four professional level staff, along with additional support staff, primarily engaged in implementation of EJ research programs. Staff have both attended and organized numerous EJ-related programs over the past decade.

The NIEHS participated in the development of the HHS EJ strategy. $\frac{130}{}$ In addition, the NIEHS developed its own Strategic Plan 2000, which includes EJ initiatives. One of the goals of the plan is to improve communications with Spanish speaking and minority communities by translating public education materials into Spanish. Another goal is to ensure that press releases target minority presses such as the western U.S. Asian-American press and African-American publications.

The NIEHS regularly evaluates the work of its grantees, and significantly, has conducted an evaluation of its total EJ program. It concluded that "the program has been successful in promoting novel community-university partnerships and enabling them to develop future research and intervention strategies." $\stackrel{131}{~ T h e ~ N I E H S ~ a l s o ~ h o l d s ~ a n n u a l ~ m e e t i n g s ~ o f ~ i t s ~}$ EJ and Community-Based Prevention/Intervention Research (CBPIR) grantees that result in reports which are posted on its website. $\underline{132}$

Community outreach and public participation are key components of the EJ grant programs. EJ-related workshops, professional society conferences, and town meetings [31 ELR 11149] are regularly sponsored. All-day town meetings are held at least four times a year. Local residents can share their environmental health concerns with high-level staff of the NIEHS, including the Director. Translators are present at these meetings.

The NIEHS' Division of Extramural Research and Training supports several EJ projects, including grants to community groups and universities to forge communication links between communities that are directly affected by environmental harms, researchers, and health care providers. The goal is to ensure that researchers and health care providers work 
with these communities as they develop responses to environmental health problems and intervention strategies. It also created the ARCH program to establish research partnerships between investigators at universities with significant environmental health science research capabilities and with researchers, from minority serving institutions, who have a strong interest in such research, but lack the resources to otherwise apply for NIEHS grants.

The division also administers the CBPIR grant program, which funds research projects that facilitate the implementation of culturally relevant prevention/intervention activities in economically disadvantaged and underserved populations confronting environmental contamination. The NIEHS hopes that with improved understanding of how to prevent, detect, and treat environmentally related health problems, communities will see a reduction in these problems. EJ and CBPIR programs have been funded in Native American and Alaskan Native communities. As of May 2000, the NIEHS was funding projects in Florida, Illinois, Missouri, New York, North Carolina, Oklahoma, Oregon, Pennsylvania, and Washington.

The NIEHS further initiated a grant program to foster interdisciplinary research on the biological, social, and behavioral causes of health disparities in the U.S. population. This program was instituted following a series of regional workshops in 1999.

An additional program, the Community Outreach and Education Program (COEP), provides support to 27 NIEHSdesignated centers at institutes and universities. Each center defines the communities in which it will conduct outreach efforts aimed at addressing environmental health problems of concern to those communities.

Pursuant to a joint program of NIEHS, EPA, and the Centers for Disease Control and Prevention, eight centers have been established since 1999 to study and treat children's health problems having an environmental etiology. These centers also encourage preventative health measures, such as reducing home exposures and improving the nutritional status of the children and their families.

\section{Conclusion}

All of the federal agencies surveyed pay homage to EJ to some extent. A few have made major institutional investments in promoting and achieving EJ. Clearly, substantial federal environmental resources are now directed at minority and low-income communities, especially in brownfield development and lead-based paint remediation efforts. With the possible exceptions of HUD's Colonias, and projects by the USDA, the survey responses overall may lead one to conclude that fewer resources are directed at programs that are more likely to affect environmental conditions in Hispanic communities. For example, the agencies report substantial resources directed at the older, industrial cities, rather than to the newer urban areas of the Southwest, which have substantially different demographics than the "Frost Belt."

Words alone do not necessarily result in meaningful change. Sometimes, subtle signs, such as the creation of a website, may signify a deeper commitment to a goal. So too does the initiation of substantial new EJ programs not mandated by other statutes and regulations, the commitment of high-level agency personnel to promote EJ, $\underline{133}$ or a basic change in approach and redirection of efforts. The participation of adversely impacted communities at the beginning of the planning process is also a major sign of institutional change. Not all the agencies pass these tests. Meaningful community participation in decisionmaking is still lacking in some agencies.

All agencies had an initial burst of energy upon issuance of the EO. Carry through, though, has sometimes been problematic. Perhaps the most critical factor is the level of commitment at the highest levels of an agency. A Secretary or Administrator who makes EJ a priority, follows through with a commitment of resources and strong leadership, and requires accountability by agency employees, will see the agency respond accordingly..$\underline{134}$ No agency has apparently been dragging its feet on the issue, but clearly some stand out in their level of success. EPA, HUD, the DOT, and the NIEHS have consistently performed at a higher level. The record at the DOJ and at the DOI has been sporadic. DOE is somewhere in between. A related observation is that the USDA has a good handle on what its individual agencies are doing in the EJ area, whereas the DOJ and the DOI may not.

Significantly, the broader definition of EJ allows agencies to "label," or pass off, environmental mitigation and protection measures, otherwise required by law, as "environmental justice." $\underline{135}$ In this respect, agencies are repackaging environmental protection as EJ by simply changing a few words. Many agencies surveyed have engaged in this activity. 
Certainly, compliance with existing law, indeed the identification of existing programs that constitute EJ activities, is an excellent first step in furthering the goals of the EO. Before an agency knows where it is going, it must know where it is. However, these commendable efforts are only a first step in meeting the goals of the EO. Not every agency has undertaken the additional and important step of introducing new programs and reassessing existing programs, priorities, and policies in order to comply with both the letter and the spirit of the EO. One of the major goals of the EO was to encourage additional efforts because of dissatisfaction with the status quo.

Every agency has considerable discretionary authority to implement measures that will reduce existing environmental disparities. Agency responses may be conceptualized as a continuum: On the one end we see "repackaging" of normal [31 ELR 11150] agency activities as "EJ programs." The next strategy is to undertake discrete environmental projects, such as pilot projects and initiatives that lie outside the purview of broadly applicable requirements. The third and more advanced strategy is to design explicit EJ protections into the core design of major regulatory programs and activities. The fourth and last strategy on the continuum would be to undertake a comprehensive review of all agency EJ efforts to determine their effectiveness in impacted communities. The agencies vary in how far they have progressed. Repackaging and identifying existing programs was the norm, with a trend toward undertaking discrete new projects. Integrating EJ into program design has been relatively rare, and comprehensive assessment and analysis exceedingly uncommon. Based upon the agency responses, there appears to be only a few instances in which agencies have incorporated EJ principles and protections into programmatic design. Of course, we are at the early stages of federal agencies redirecting their efforts in light of the EO. Seven years cannot be expected to change decades, if not generations, of agency attitudes and approaches. While all agency actions that reduce disparities are admirable and constitute an advance, clearly full integration is the strategy most likely to result in significant, long-term progress.

The extent to which present progress will continue and evolve, or conversely, wither on the vine, is not presently ascertainable. The start is promising and provides reason for optimism.

If the question is posed as: "Has the EO furthered the way the government addresses environmental justice issues?," then the response is that a series of actions have been taken, which probably would not otherwise have been initiated, the significance of which varies by individual agency. It is also clear that voices have been heard, but the extent to which they have been listened to varies substantially. ${ }^{-136}$ The longterm results are not presently ascertainable or even predictable. Whether or not the change in Administrations will make a difference in the agencies' continuing responsiveness to EO No. 12898 also remains unknown at this time.

1. Federal Actions to Address Environmental Justice in Minority Populations and Low-Income Populations, Exec. Order No. 12898, 3 C.F.R. 859 (1995), reprinted in 42 U.S.C. § 4321, ADMIN. MAT. 45075.

2. This report has a cutoff date of Feb. 1, 2001, which roughly reflects the change in Administrations. We have tried to be inclusive as of the end of January 2001.

3. See, e.g., the germinal zoning case of Yick Wo v. Hopkins, 118 U.S. 356 (1886) (attempt by San Francisco to exclude Chinese laundries). The distinguished urban planner, Victor Gruen, related a story about Grosse Pointe, Michigan, in the 1950s. The Grosse Pointe Property Screening Committee employed a three-page questionnaire to screen prospective purchasers in the community. Points were given on such characteristics as descent, way of life, occupation, swarthiness, accent, name, repute, education, dress, and status of occupation. Religion was not scored, but was weighed in the balance. Prospects were handicapped on ethnicity and race, such that Jews would have to score 85 points, Italians 75, Greeks 65, and Polish Americans 55. African Americans and Asian-Pacific Islanders did not count. Ironically, the community's permanent residents included three Detroit gangsters with a collective score of 61 points. See VICTOR GRUEN, THE HEART OF OUR CITIES: THE URBAN CRISIS: DIAGNOSIS AND CURE 105-06 (1964) (quoting from the Apr. 25, 1960 issue of Time magazine).

4. See especially Warth v. Seldin, 422 U.S. 490 (1975) and Southern Burlington County NAACP v. Township of Mt. Laurel, 336 A.2d 713 (N.J. 1975) (Mt. Laurel I).

5. See especially United States v. City of Black Jack, 508 F.2d 1179 (8th Cir. 1974), cert. denied, 422 U.S. 1042 (1974) and Hawkins v. Town of Shaw, 437 F.2d 1286 (5th Cir. 1971), reh'g en banc, 462 F.2d 1171 (5th Cir. 1972). See generally CHARLES M. HAAR \& DANIEL W. FESSLER, THE WRONG SIDE OF THE TRACKS (1986). 
6. Robert W. Bullard, Solid Waste Sites and the Black Houston Community, 55 SOC. INQUIRY 273 (1983). See also Robert W. Bullard Race and Environmental Justice in the United States, 18 J. INT'L L. 319 (1993); Robert W. Bullard, Unequal Environmental Protection: Incorporating Environmental Justice in Decision-Making, in WORST THINGS FIRST? THE DEBATE OVER RISK-BASED NATIONAL PRIORITIES 243 (Adam M. Finkel \& Dominic Golding eds., 1994).

7. U.S. GAO, SITING OF HAZARDOUS WASTE LANDFILLS AND THEIR CORRELATION WITH RACIAL AND ECONOMIC STATUS OF SURROUNDING COMMUNITIES (1983).

8. COMMISSION FOR RACIAL JUSTICE, UNITED CHURCH OF CHRIST, TOXIC WASTES AND RACE IN THE UNITED STATES: A NATIONAL REPORT ON RACIAL AND SOCIO-ECONOMIC CHARACTERISTICS OF COMMUNITIES WITH HAZARDOUS WASTE SITES (1987).

9. Lead is widely regarded as the most serious environmental health hazard facing young children today. Lead poisoning disproportionately impacts low-income and minority children. See, e.g., Clifford Rechtschaffen, How to Reduce Lead Exposures With One Simple Statute: The Experience of Proposition 65, 29 ELR 10581, 10582 (Oct. 1999).

10. U.S. EPA, ENVIRONMENTAL JUSTICE, available at http://www.es.epa.gov/occa/main/ej/ (last visited July 10, 2001). See also Memorandum from Barry E. Hill, Director, Office of Environmental Justice, EPA, to Deputy Regional Administrator, EPA et al. (Dec. 16, 1998) (quoting OFFICE OF SOLID WASTE, U.S. EPA, GUIDE TO ENVIRONMENTAL ISSUES-EARTH DAY 25 EDITION (1995) (EPA/OSWER Directive No. 520/B-94-001)).

11. See also 59 Fed. Reg. 7629 (Feb. 11, 1994).

12. Indeed, a coalition of environmental justice organizations called on President Clinton on Feb. 11, 2000, to compile a status report on the EO. 31 Env't Rep. (BNA) 303 (Feb. 18, 2000).

13. The agencies selected are ones whose policies and programs have great potential to affect environmental justice issues in minority and low-income communities.

14. Professors Gauna and O'Neill.

15. Professor Binder.

16. Professor Crawford.

17. Professor Rechtschaffen.

18. Professor Verchick.

19. Professor Mank.

20. Professor Kaswan.

21. Professor Jarman.

22. 42 U.S.C. §§ 4321-4370d, ELR STAT. NEPA §§ 2-209.

23. Transcript of the Sixteenth Meeting of the Environmental Justice Advisory Council (Dec. 12, 2000) [hereinafter NEJAC].

24. For example, because of the decentralization of power into the individual bureaus of the DOI, it is not always possible to compile data on subjects, such as the total number of Title VI cases involving the agency or the number of EJ-oriented grants.

25. See http://www.em.doe.gov/public/envjust/resources.html (last visited July 10, 2001). 
26. Detailed information on the EJ activities at the eight DOI bureaus can be found at http://www.doi.gov loepc/ej_examples.html (last visited July 10, 2001).

27. For example, the USDA, in partnership with the Naval District in Washington, D.C., worked to institute a National Urban Internet program designed to provide computer access and training to public housing residents in southeast Washington. It included modules with information on the environment and government rulemaking.

28. We recognize that the EO only required reports to be prepared for the President and Interagency Working Group within varying time spans ranging up to 24 months from the date of the order. However, the EO also provides that "federal agencies shall provide additional periodic reports to the Working Group as requested by the Working Group." Exec. Order No. 12898, supra note 1, § 1-103(g), ADMIN. MAT. at 45075. It is the follow-up reports that are often lacking.

29. The demonstration projects are located in San Diego, California; Colorado; Washington, D.C.; Chicago, Illinois; Boston, Massachusetts; East St. Louis and New Madrid County, Missouri; Ft. Belknap, Montana; Camden, New Jersey; Albuquerque, New Mexico; Oregon; and Spartanburg, South Carolina. The projects include environmental cleanups, public health issues, children's health concerns, economic development, and community capacity building.

30. For example, the USDA sent special notices to rural communities participating in its programs and provided assistance in application and development of EPA-sponsored brownfield initiatives in Metlakatla, Alaska; a tribal area also in Alaska; and in Cape Charles, Virginia. Brownfields are contaminated areas to be cleaned up for future development.

31. At the time this report was being prepared, the Supreme Court decided Alexander v. Sandoval, 121 S. Ct. 1511 (2001), the effects of which may be significant in determining the practical effects of Title VI, but are beyond the scope of this survey.

32. Presidential Memorandum Accompanying Executive Order No. 12898, 30 WEEKLY COMP. PRES. DOC. 279 (Feb. 11, 1994) (available from the ELR Document Service, ELR Order No. AD-1134).

33. 42 U.S.C. § 2000d. See, e.g., Nondiscrimination in Programs Receiving Federal Assistance From the Environmental Protection Agency, 40 C.F.R. § 7 (EPA implementing regulations); id. § 7.35(b) ("A recipient [of federal funds] shall not use criteria or methods of administration which have the effect of subjecting individuals to discrimination because of their race, color, [or] national origin."). See generally 38 Fed. Reg. 17968 (July 5, 1973), as amended by 49 Fed. Reg. 1659 (Jan. 12, 1984) (codified at 40 C.F.R. pt. 7).

34. U.S. EPA, Draft Title VI Guidance for EPA Assistance Recipients Administering Environmental Permitting Programs (Draft Recipient Guidance) and Draft Revised Guidance for Investigating Title VI Administrative Complaints Challenging Permits (Draft Revised Investigation Guidance), 65 Fed. Reg. 39650, 39651-54 (June 27, 2000) (available from the ELR Document Service, ELR Order Nos. AD-4517 (Draft Recipient Guidance) and AD-4516 (Draft Revised Investigation Guidance)). See Eileen Gauna, EPA at 30: Fairness in Environmental Protection, 31 ELR 10528, 10540 (May 2001); Bradford C. Mank, The Draft Title VI Recipient and Revised Investigation Guidances: Too Much Discretion for EPA and a More Difficult Standard for Complainants?, 30 ELR 11144 (Dec. 2000).

EPA may be reluctant, though, to take the next step and actually impose sanctions against recipients, which include numerous state agencies. Both states and industry pressure EPA to encourage rather than discourage economic development. EPA has, to date, decided only one case on the merits after an investigation. ${ }^{35}$ The Agency stated that a recipient's compliance with EPA's health-based national ambient air quality standards (NAAQS) created a presumption of no significant adverse effects on minority groups, unless the complainant could present evidence that the standards were insufficient to protect a particular minority in a specific area.

35. See Letter from Ann E. Goode, Director, EPA's OCR, Re: EPA File No. 5R-98-R5 (Select Steel Complaint) to Father Phil Schmitter, Co-Director, St. Francis Prayer Center [Complainant] and Michigan Department of Environmental Quality [Recipient] (Oct. 30, 1998); St. Francis Prayer Ctr. v. Michigan Dep't of Envtl. Quality, EPA File No. 5R-98-R5 (Select Steel) (dismissing Title VI complaint against Michigan Department of Environmental 
Quality).

36. USDA, NONDISCRIMINATION IN PROGRAMS AND ACTIVITIES RECEIVING FEDERAL FINANCIAL ASSISTANCE FROM USDA, DEPARTMENTAL REGULATION 4330-2 (Mar. 3, 1999), available at http:www/usda /gov/da/4330-2.pdf (last visited July 12, 2001).

37. Exec. Order No. 12250, 45 Fed. Reg. 72995 (Nov. 2, 1980).

38. The DOJ noted in a 1998 report that the Housing Section of the Civil Rights Division reviewed and found without merit several civil rights complaints raising EJ issues. U.S. DOJ, REPORT ON ENVIRONMENTAL JUSTICE 4 (1998). The report does not specify whether the complaints were based on Title VI or if the complaints were made against recipients of DOJ funding.

39. See Letter from Diana Ortiz, Director, Office of Enforcement, HUD Office for Fair Housing and Equal Opportunity, to Alice Kaswan (June 26, 2001).

40. HUD, A COMMITMENT TO COMMUNITIES: ACHIEVING ENVIRONMENTAL JUSTICE, AN IMPLEMENTATION REPORT (1996), available at http://www.hud.gov/cpd/ocv/ej.html (last visited July 10, 2001).

41. COUNCIL ON ENVIRONMENTAL QUALITY (CEQ), ENVIRONMENTAL JUSTICE GUIDANCE UNDER THE NATIONAL ENVIRONMENTAL POLICY ACT (1997), available at http://ceq.eh.doe.gov/nepa/regs/ej/ej.pdf (last visited July 10, 2001) [hereinafter CEQ, ENVIRONMENTAL JUSTICE GUIDANCE].

42. See, e.g., Baltimore Gas \& Elec. Co. v. Natural Resources Defense Council, 462 U.S. 87, 13 ELR 20544 (1983).

43. Of course, some major agency acts and activities, such as Resource Conservation and Recovery Act (RCRA) permitting, are effectively exempt from NEPA requirements under the functional equivalency exemption or by statute.

44. U.S. EPA, GUIDANCE FOR INCORPORATING ENVIRONMENTAL JUSTICE CONCERNS IN EPA'S NEPA COMPLIANCE ANALYSIS_DRAFT (1996) (available from the ELR Document Service, ELR Order No. AD-3008) [hereinafter EPA, NEPA COMPLIANCE].

45. 42 U.S.C. § 7609, ELR STAT. CAA § 309.

46. U.S. EPA, GUIDANCE FOR INCORPORATING ENVIRONMENTAL JUSTICE CONCERNS IN EPA'S NEPA COMPLIANCE ANALYSIS (1998) (available from the ELR Document Service, ELR Order No. AD-3856).

47. See CEQ, ENVIRONMENTAL JUSTICE GUIDANCE, supra note 41.

48. U.S. EPA, FINAL GUIDANCE FOR CONSIDERATION OF ENVIRONMENTAL JUSTICE IN CLEAN AIR ACT $\S 309$ REVIEWS (1999) (available from the ELR Document Service, ELR Order No. AD-4219).

49. See EPA, NEPA COMPLIANCE, supra note 44.

HUD reported that its field environmental officers and field staff have all received copies of the CEQ's guidelines for incorporating EJ concerns into NEPA documents. HUD defined key terms by reference to the CEQ guidelines. HUD's Manual for HUD Staff to Conduct an Environmental Review includes EJ as a "compliance component" necessary for EAs. $\frac{50}{}$ In addition, HUD ensures compliance with NEPA and the EO by including a section on EJ in its standard form

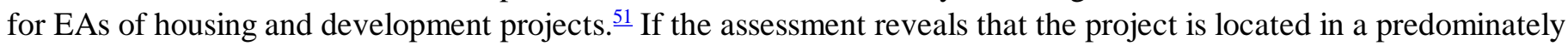
minority or low-income neighborhood that suffers from disproportionately adverse environmental effects, then the form explicitly states that compliance with the EO is required. $\underline{52}$

50. The manual is available through HUD's website at http://www.hud.gov/cpd/ocv/envrvw/tngm (last visited July 10, 2001).

51. HUD, FORM 4128, available at http://www.hud.gov/cpd/ocv/envregul (last visited July 10, 2001). 
52. Id.

53. This provision is discussed in detail in the DOT section, infra.

54. See Draft Recipient Guidance, supra note 34, at 39658.

55. See http://www.hud.gov/cpd/ocv/ej.html (last visited July 10, 2001).

56. See http://www.epa.gov/indian/trabhand.html (last visited July 10, 2001).

57. For example, no current EPA document provides a comprehensive picture of EPA's efforts to comply with the EO.

58. OEJ, U.S. EPA, ENVIRONMENTAL JUSTICE SMALL GRANTS PROGRAM: EMERGING TOOLS FOR LOCAL PROBLEM SOLVING (1999) (EPA 200-R-99-001), available at http://es.epa.gov/oeca/success.pdf (last visited July 10, 2001).

59. U.S. GAO, BROWNFIELDS: INFORMATION ON THE PROGRAMS OF EPA AND SELECTED SITES (2001). Brownfield development is a high priority for the federal government because it can help restore the vitality of cities and alleviate suburban sprawl. NEJAC, supra note 23, at I-85.

60. NEJAC, supra note 23, at I-148.

61. USDA, ENVIRONMENTAL JUSTICE, DEPARTMENTAL REGULATION 5600-2, at 3 (1997).

62. Consultation and Coordination With Indian Tribal Governments, Exec. Order No. 13084, 63 Fed. Reg. 27655 (May 14, 1998), ADMIN. MAT. 45095.

63. Consultation and Coordination With Indian Tribal Governments, Exec. Order No. 13175, 65 Fed. Reg. 67249 (Nov. 9, 2000).

64. U.S. DOJ, REPORT TO THE ENVIRONMENTAL JUSTICE WORKING GROUP ON ACCOMPLISHMENTS UNDER EXECUTIVE ORDER 12898, at 7 (1999).

65. This agency was historically known as the Soil and Conservation Service.

66. U.S. EPA, Office of Environmental Justice Small Grants Program; Application Guidance FY 2001, 65 Fed. Reg. 81720 (Dec. 26, 2000).

67. Press Release, U.S. EPA, Press Release R-197, Brownfield Communities Get \$ 1.8 Million for Job Training (Dec. 21, 2000). The GAO concluded that for FY 1995 through FY 2000, EPA provided \$ 246.9 million for brownfield assistance. See U.S. GAO, supra note 59.

68. OFFICE OF SOLID WASTE \& EMERGENCY RESPONSE, U.S. EPA, PUBLIC INVOLVEMENT IN ENVIRONMENTAL PERMITS: A REFERENCE GUIDE (2000) (EPA 500-R-00-007), available at http://www.epa.gov/permits/publicguide.htm (last visited July 10, 2001).

69. U.S. EPA, Draft Public Involvement Policy, 65 Fed. Reg. 82335 (Dec. 28, 2000).

70. Id. at 82340 .

71. Id. at 82338.

72. Id. at 82338-44.

73. EPA established in 1992 a three-judge EAB as the final Agency decisionmaker in administrative appeals.

74. See generally In re Chemical Waste Mgmt. of Ind., Inc., RCRA Appeal Nos. 95-2, -3, 6 E.A.D. 66, 1995 WL 
395962, ADMIN. MAT. 40392 (June 29, 1995).

75. In addition to In re Chemical Waste Mgmt., the other cases are: (1) prevention of significant deterioration (PSD) cases, In re Genesee Power Station, L.P., PSD Appeal Nos. 93-1 et al., 1993 WL 484880, modified by In re Genesee Power Station, L.P., 4 E.A.D. 832, EPA App. LEXIS 23, ADMIN. MAT. 40969 (Oct. 22, 1993); In re Puerto Rico Elec. Power Auth. (Cambalache Combustion Turbine Project), PSD Appeal No. 95-2, 6 E.A.D. 253, 1995 EPA App. LEXIS 38, ADMIN. MAT. 40452 (Dec. 11, 1995); In re EcoElectrica, L.P., PSD Appeal Nos. 96-8, -13, 7 E.A.D. 56, 1997 EPA App. LEXIS 5, ADMIN. MAT. 40632 (Apr. 8, 1997); In re AES Puerto Rico, L.P., PSD Appeal Nos. 98-29 et al., 1999 EPA App. LEXIS 17, ADMIN. MAT. 41132 (May 27, 1999); In re Knauf Fiber Glass, GmbH, PSD Appeal Nos. 98-3 et al., post remand appeal EPA App. LEXIS 2, ADMIN. MAT. 41053 (Feb. 4, 1999) (Knauf I), In re Knauf Fiber Glass, Gmbh, ADMIN. MAT. 41218 (Mar. 14, 2000) (Knauf II); (2) RCRA cases, In re Chemical Waste Mgmt.; In re Ash Grove Cement Co., RCRA Appeal Nos. 96-4, -5, 7 E.A.D. 387, 1997 EPA App. LEXIS 30, ADMIN. MAT. 40732 (Nov. 14, 1997); (3) SDWA cases, In re Envotech, L.P., UIC Appeal Nos. 95-2 et al., 6 E.A.D. 260, 1996 EPA App. LEXIS 4, ADMIN. MAT. 40454 (Feb. 15, 1996); In re Environmental Disposal Sys., Inc., UIC Appeal Nos. 98-1, -2, 1998 EPA App. LEXIS 105, ADMIN. MAT. 41073 (Oct. 15, 1998). See U.S. EPA, Environmental Appeals Board Format Opinions, at http://www.epa.gov/eab/chrono.htm (last visited July 10, 2001); Guana, supra note 34, at 10532-39.

76. In re Chemical Waste Mgmt., 1995 WL 395962, at *3, ADMIN. MAT. at 40393.

77. Richard J. Lazarus \& Stephanie Tai, Integrating Environmental Justice Into EPA Permit Authority, 26 ECOLOGY L.Q. 617, 664 (1999).

78. This provision was likely a response in part to a 1992 National Law Journal study that alleged the EPA was less likely to bring enforcement actions in poor and minority neighborhoods.

79. U.S. EPA, ENVIRONMENTAL JUSTICE STRATEGY: EXECUTIVE ORDER 12898 1-2 (1995) (available from the ELR Document Service, ELR Order No. AD-1177).

80. See Deputy Administrator Speeches, EPA Deputy Administrator Fred Hansen's Remarks Prepared for Delivery to the Martin Luther King Tribute 1998 (Jan. 22, 1998), at http://www.yosemite.epa.gov/opa/asadspch.nsf/ (last visited Dec. 29, 2000); Guana, supra note 34, at 10528.

81. OEJ, U.S. EPA, ENVIRONMENTAL JUSTICE IMPLEMENTATION PLAN (1996) (EPA 300-R-96-004).

82. See U.S. EPA, PROMOTING ENVIRONMENTAL JUSTICE THROUGH POLLUTION PREVENTION (2000)

(EPA 742-K-00-001), available at http://www.epa.gov.gov/oppt/ejp2 (last visited July 10, 2001).

83. U.S. EPA, ASSESSMENTS OF U.S. EPA EJP2 GRANT PROGRAMS (2000), available at http://www.epa /gov/oppt/ejp2 (last visited July 10, 2001).

84. 66 Fed. Reg. 11289 (Feb. 23, 2001); U.S. EPA, 2001 GRANT GUIDANCE (2001) (EPA 742-B-01-001).

85. These measures are partially achieved through an MOU concerning an Idaho cleanup, having tribes serve as co-trustees on sites in Nevada and the Great Lakes area, contracting with Native American-owned businesses to perform cleanup actions, and working with residents in Magdalena, New Mexico, to address contamination at a former BIA Indian school facility. NEJAC, supra note 23, at I-181.

86. Appendix C to DR 5600-2 catalogues scores of initiatives or programs that the USDA considers related to EJ. Some of these efforts appear designed to address disparities in environmental burdens borne and benefits received between communities of color, low-income populations, and Native peoples on one hand and majority or affluent populations on the other. Other USDA efforts appear designed merely to serve low-income, minority communities, and Native American communities alongside majority or affluent communities with no apparent aim of reducing disparities between these groups.

87. Atlanta, Chicago, Denver, East St. Louis, Los Angeles, New York, Philadelphia, and Seattle. 
88. NRCS, ENVIRONMENTAL JUSTICE: PERCEPTIONS OF ISSUES, AWARENESS, AND ASSISTANCE (Social Sciences Inst. Tech. Rep., July 2000).

89. Survey respondents were identified as 51\% African American and 47\% Caucasian.

90. For example, the CSREES has worked with the University of Alaska to convey this information to Alaskan natives.

91. Professor Binder relied on the NEJAC transcript and a 1996 DOE report in preparing this section.

92. NEJAC, supra note 23, at 1-107.

93. U.S. DOE, ENVIRONMENTAL JUSTICE STRATEGY (1995).

94. U.S. DOE, PROGRESS REPORT TO THE PRESIDENT ON IMPLEMENTATION OF ENVIRONMENTAL JUSTICE STRATEGY, EXECUTIVE ORDER 12898 (1996).

95. As is well known, DOE possesses many nuclear facilities, which go back as far as World War II, and which necessitate substantial cleanup efforts. These facilities, especially during the Cold War, did not emphasize environmental quality.

96. This roundtable brought together 50 different Native American community groups and others. NEJAC, supra note 23, at I-78.

97. Id. at I-108.

98. Princeville is regarded as the birthplace of African-American freedom. Founded by slaves in 1865 and originally called Freedom Hill, in 1885, it became the first African-American incorporated town in the United States. See http://clinton4.nara.gov/WH/New/html/20000229_1.html (last visited July 10, 2001).

99. NEJAC, supra note 23, at I-108-109.

100. Id. at I-109.

101. Information about HUD throughout this Article was obtained from the following sources: HUD, ACHIEVING ENVIRONMENTAL JUSTICE-A DEPARTMENTAL STRATEGY (1995) and HUD, A COMMITMENT TO COMMUNITIES: ACHIEVING ENVIRONMENTAL JUSTICE, AN IMPLEMENTATION REPORT (1996). These reports were prepared pursuant to the EO, and are available through HUD's website at http://www.hud.gov/cpd/ocv lej.html. HUD's response to our survey was prepared by Mr. Richard Broun, HUD's Office of Community Viability, Community Planning, and Development Department, as supplemented by materials available on HUD's website and elsewhere on the Internet.

102. See 42 U.S.C. $\S ~ 4851 ; 24$ C.F.R. § 35.80; 40 C.F.R. § 745.100.

103. Lead-based paints were common in housing built before 1978.

104. HUD-associated housing includes public housing, private housing assisted under the block grant program, and housing assisted by single-family mortgage insurance.

105. The bureaus are: National Park Service, the U.S. Fish and Wildlife Service, BIA, Bureau of Land Management, Office of Surface Mining, the MMS, U.S. Geological Service, and the Bureau of Reclamation.

106. An example of this information gathering is a multiyear study, A Quantitative Description of Potential Impacts of OCS Activities on Bowhead Whale Hunting and Subsidence Activities in the Beaufort Sea and Recommended Mitigation Including Compensation.

107. U.S. DOJ, ENVIRONMENTAL JUSTICE STRATEGY (1995). 


\section{U.S. DOJ, GUIDANCE CONCERNING ENVIRONMENTAL JUSTICE 5-6 (1995).}

109. Id. at 8-9.

110. See U.S. DOJ, IMPLEMENTATION OF EXECUTIVE ORDER 12898 (2000) (report provided to the CEQ.) Chester is a predominately African-American community that has gained a high profile in EJ debates because of the high concentration of polluting facilities that it hosts.

111. These efforts have led, for example, to settlements with several major Washington, D.C., landlords, resulting in the commitment of over \$ 2 million for lead poisoning prevention measures. NEJAC, supra note 23, at I-85.

112. For example, U.S. DOJ, REPORT TO THE ENVIRONMENTAL JUSTICE WORKING GROUP ON ACCOMPLISHMENTS UNDER EXECUTIVE ORDER 12898 (1996) cites two such instances. The DOJ was unable to identify any cases in the four years since then.

113. Chester Residents Concerned for Quality Living v. Seif, 132 F.3d 925, 28 ELR 20487 (3d Cir. 1997), cert. granted, 118 S. Ct. 2296, vacated as moot, 119 S. Ct. 22 (1998). The Supreme Court implied in Alexander v. Sandoval, 121 S. Ct. 1511 (2001), that no private cause of action exists under Title VI. But see South Camden Citizens in Action v. New Jersey Dep't of Envtl. Protection, 2001 U.S. Dist. LEXIS 5988 (May 10, 2001), appeal pending (despite holding in Sandoval that Title VI did not authorize a direct implied private right of action to remedy disparate impact discrimination, plaintiffs could in the alternative pursue their Title VI discrimination claims thorough 42 U.S.C. § 1983).

114. NEJAC, supra note 23, at I-89.

115. The Federal Maritime Administration, for example, has to deal with ship scrapping, which can release polychlorinated biphenyls into local waters or streams. Id. at I-117.

116. These organizations include the FHwA, the FTA, the FAA, the Office of Science and Technology, the Federal Railroad Administration, the American Association of State Highway and Transportation Officials, the American Public Transportation Association, and the American Metropolitan Planning Association.

117. NEJAC, supra note 23, at I-114.

118. U.S. DOT, Order to Address Environmental Justice in Minority Populations and Low-Income Populations, 62 Fed. Reg. 18377 (Apr. 15, 1997) (DOT Order 5610.2). The DOT order is a response to the EO, and addresses only minority and low-income populations. It does not therefore provide for separate consideration for the elderly, children, or the disabled. Furthermore, as an internal directive, it may not create rights of judicial review.

119. The agency's earlier announcement of it EJ strategy appears at U.S. DOT, Environmental Justice Strategy, 60 Fed. Reg. 33896 (June 29, 1995).

120. 62 Fed. Reg. at 18379.

121. Id. at 18380.

122. Id. In making such assessments, "all offsetting benefits to the affected minority and low-income populations may be taken into account, as well as ... the relevant number of similar existing system elements in non-minority and low-income areas." Id.

123. Id. at 18380-81, app. 1.f. (defining "adverse effects"). Such effects may include: bodily impairment, infirmity, illness or death; air, noise, and water pollution and soil contamination; destruction or disruption of man-made or natural resources; destruction or diminution of aesthetic values; destruction or disruption of community cohesion or a community's economic vitality; destruction or disruption of the availability of public and private facilities and services; vibration; adverse employment effects; displacement of persons, businesses, farms, or nonprofit organizations; increased traffic congestion, isolation, exclusion or separation of minority or low-income individuals within a given community or from the broader community; and the denial of, reduction in, or significant delay in the receipt of, 
benefits of DOT programs, policies, or activities. Id at 18381. A "disproportionately high and adverse effect on minority and low-income population" means an "adverse effect" that either "is predominately borne by a minority population and/or low-income population and is appreciably more severe or greater in magnitude than the adverse effect that will be suffered by the non-minority population and/or low-income population." Id. app. 1.g.(1)-(2).

124. Id. at 18380. "In determining whether a mitigation measure or an alternative is 'practical,' the social, economic (including costs) and environmental effects of avoiding or mitigating the adverse effects will be taken into account." Id.

125. Id. These standards are, of course, similar to the famous $\S 4 \mathrm{f}$ of the Federal Highway Act requirements for siting

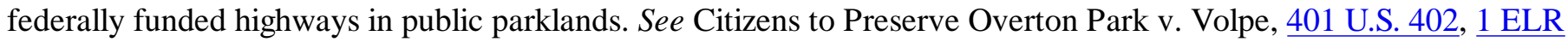
$\underline{20110}$ (1971).

126. See FHwA, U.S. DOT, FHwA ACTIONS TO ADDRESS ENVIRONMENTAL JUSTICE IN MINORITY POPULATIONS AND LOW-INCOME POPULATIONS, ORDER 6640.23 (1998).

127. 62 Fed. Reg. at 18381, app. 5.b.

128. Id. app. 5.b.(1)-(3).

129. Id. app. 3.d.

130. NIEHS is currently the only agency at NIH with explicit responsibility for EJ.

131. Correspondence from Dr. Allen Dearry, Division of Extramural Research and Training (Sept. 8, 2000).

132. See http://www.niehs.nih.gov/dert/programs/translat/envjust/envjust.htm (last visited July 10, 2001).

133. The difference in approach between agencies, such as the DOT, the USDA and EPA, which have prioritized EJ at the highest levels of the agency, versus the DOI and the DOJ, which have dispersed EJ responsibilities throughout the agencies, is significant.

134. For example, the USDA requires the submission of annual reports to its Environmental Justice Steering Committee and the Under Secretary for Natural Resources and Environment.

135. The DOI has been forthright in acknowledging the overlap in this respect.

136. Cf. PAUL SIMON, THE SOUNDS OF SILENCE (BMI Records 1964).

31 ELR 11133 | Environmental Law Reporter | copyright (C) 2001 | All rights reserved 